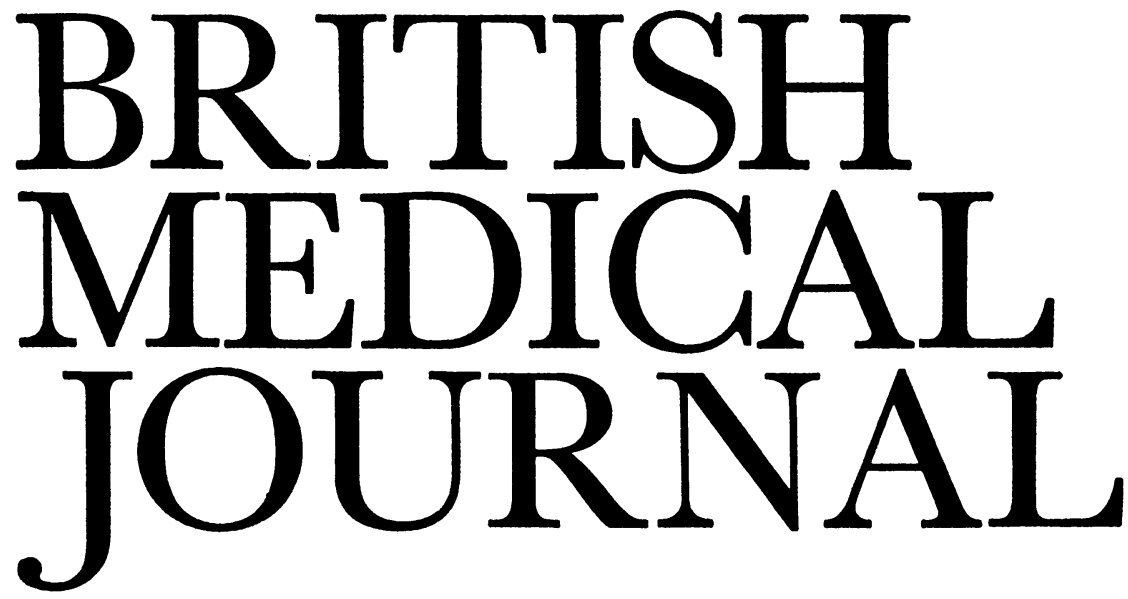

LONDON SATURDAY 4 NOVEMBER 1972

\title{
Colleagues in Africa
}

When Great Britain relinquished its protectorate of Uganda just 10 years ago it left as a parting present one of the finest hospitals on the African continent. Standing on Mulago Hill on the outskirts of Kampala, it was more than a splendid group of buildings. Successor to the thatched hut in which Dr. (later Sir) Albert Cook began his practice in 1897, it was a refuge where the sick from all parts of the country received first-class medical attention from doctors of many races and nationalities. At the same time Mulago Hospital and its associated medical school were a centre of outstanding research, where fundamental work was done (to cite two renowned examples) by $\mathrm{Mr}$. Denis Burkitt on the tumour that bears his name and by Professor S. M. M. Karim on the prostaglandins. The staff was naturally mainly Ugandan, among them many Asians, but Britons, Scandinavians, Americans, and other nationals contributed to the running of a great multiracial institution.

Now as a result of recent political edicts made against the Asians the medical services in Uganda are seriously weakened. The consequences for the health of the people there cannot at present be clearly seen, but what must be inescapable is the heavy burden suddenly thrown on to the doctors of Ugandan African descent. These include experts with international reputations in their specialties, experienced administrators, and men of humbler but no less needed ambition working in the remote hospitals. Yet in total they are far below the country's needs, and for some years Uganda has sought to attract doctors from overseas to man its hardpressed services. Indeed a considerable number of British doctors are still practising there, not merely at Mulago but in hospitals far afield.

In all this turmoil the Uganda Medical Association, which is affiliated to the British Medical Association, has a task that will tax the diplomacy and perhaps the resolution too of its leaders. Racial discrimination, whether under the cloak of political, religious, or biological doctrines, is peculiarly repugnant to doctors wherever they may be, because it flatly contradicts the tradition and guiding ethic of their profession, by which they treat all men alike irrespective of their colour, creed, or nationality. Medical men have a duty to their colleagues and to their profession to stand by this principle, to act on it where they can, and when the overwhelm- ing force of the State goes against it to mitigate the injury as best they may. To its credit the Medical Association of South Africa, which is likewise affiliated to the B.M.A. and has to exist in a regime where racial discrimination is embodied in statute law, has always opposed the differential terms imposed by the State on doctors of different racial origin.

Up to a point a national medical association containing most of the doctors in a country will inevitably reflect the attitudes and prejudices and even the passions that form part of that country's mythology. Doctors after all are citizens of a country with a formative history and a living present. But they also by virtue of their profession and its ethic look beyond national frontiers to the care of suffering individuals irrespective of their race and nationality. The South African Medical fournal ${ }^{1}$ has recently made its association's policy plain (as it has done on previous occasions) in stating that it goes further than deprecating that country's racial discrimination between members of the medical profession by referring to the position of patients in these words: "We do not recognize discrimination on any racial or religious grounds." The association there deserves all the support it can get in a situation that it consistently seeks to remedy.

Doctors in both these countries-and doubtless others too could be cited-sometimes have to face problems that make great demands on their conscience and their courage. Though their cultural heritage, political context, and professional training vary somewhat from place to place, all are members of a profession whose aim is the improvement of man's wellbeing, and in their endeavours to achieve that aim they have a right to know that they can draw strength through the sympathetic concern of colleagues elsewhere.

But if Uganda is to be the poorer for the loss of its Asian doctors Britain should ensure that we quickly find an honourable place for them in our own community. Difficulties of language and training will be slight and soon overcome. The Health Service has vacancies. It is to be hoped that suitable training to meet the requirements of practice in Britain will be offered wherever it is needed.

1 South African Medical fournal, 1972, 46, 1066. 